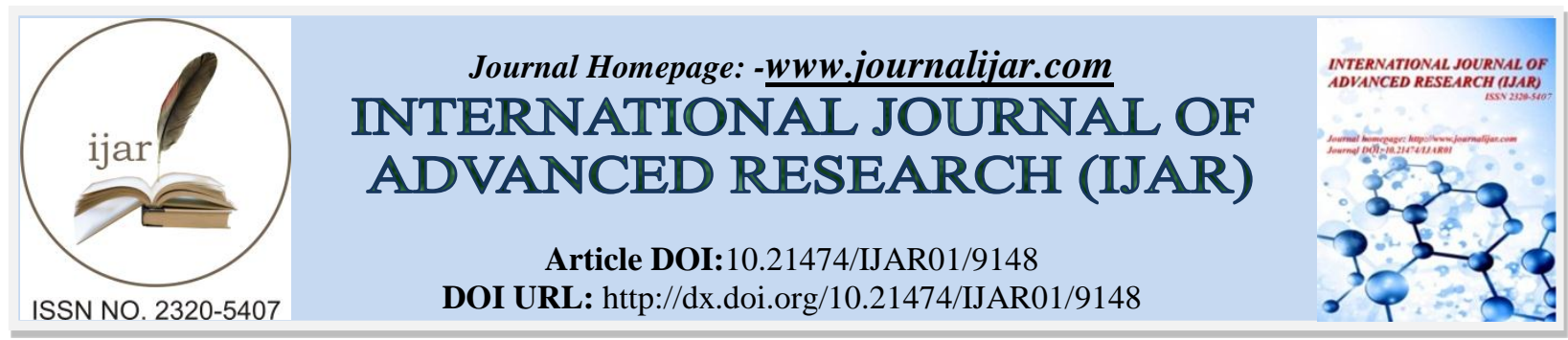

RESEARCH ARTICLE

\title{
STUDY OF DIFFERENT SIMULATION SOFTWARE'S FOR OPTIMIZATION AND ECONOMIC ANALYSIS OF PHOTOVOLTAIC SYSTEM.
}

Ashish Grover ${ }^{1}$, Dr. Anita Khosla ${ }^{1}$ and Dr. Dheeraj Joshi ${ }^{2}$.

1. Manav Rachna International Institute of Research \& Studies, Faridabad, India.

2. Delhi Technical University, Delhi, India.

\section{Manuscript Info}

Manuscript History

Received: 24 March 2019

Final Accepted: 26 April 2019

Published: May 2019

Key words:-

photovoltaic system; simulation

tools; performance

ratio;optimization.

\section{Abstract}

Numerous simulation software's\& products have been created to streamline photovoltaic system. Researchers utilized these reenactment devices with the aimthat PV Power plant may be examined prepractically with latest optimization method and cost-effective analysis to keep away the framework from over-measure, poor dependability, and high establishment cost. In this paper, software based on renewable projects with their fundamental highlights and use of instruments are discussed in detail. The virtual products such asSolar Advisor Model (SAM), PVsyst, Hybrid Optimization Model for Electric Renewable(HOMER), PV*SOL, RETScreen Clean Energy Management Software (RETScreen), Solarius PV, HelioScope, SolarPro are explicate to use in designing the PV based system., The principle goals of this paper are to feature the appropriate programming for execution investigation of PV Power plant before practical installation. After study it has been observed that Homer, SAM, RETScreen and PVsyst are the best and reasonable programming software for execution investigation. There is a need for a few enhancements in these software'sand joining of broad meteorological and PV framework parts database.

Copy Right, IJAR, 2019,. All rights reserved.

\section{Introduction:-}

In the ongoing years, Renewable sources assume imperative job in the generation of a few energies utilized in the world, and wind up a standout amongst the most noteworthy sources utilized for power age without utilizing nonrenewable energy source, similar to gas, oil, and coal. This diminishes natural contamination and prevents the atmosphere from global warming. Solar based Photovoltaic innovation is a standout amongst the most essential recourses of sustainable power source; subsequently, there is a need to create programming devices which can decide the potential vitality yield attributes and working execution of PV system. This will help of block diagram in fig.1, the design components of grid connected PV system is shownbelow.

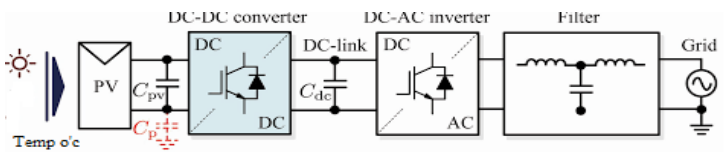

Fig 1:-Block Diagram of PV grid connected Power Plant 
Programming devices identified with photovoltaic hybrid systems can be characterized into four classes: prefeasibility, measuring, reenactment and open design explore instruments, relies on the reason for the product [1]. Energy delivered by a PV module depends extraordinarily on PV materials and sun powered isolation. After some time, the electrical vitality yield will diminish, normally because of stickiness, warm cycling, ultra-violet radiation and dampness entrance, these prompts some perpetual corruption, in particular erosion, staining, delimitation and breakage furthermore, breaking cells. Other than the inside variables, one natural factor that essentially lessens the vitality delivered by a PV module briefly is dust, however PV execution could be recuperated to its most extreme limit by cleaning exercises [2].Ethylene Vinyl Acetate(EVA) regularly corrupts amid long haul field task upon presentation to UV beams present in daylight causes staining, module changed shading to yellow or dark colored, this prompts low transmissivity of light and the power produced by the module is lessened. Breaking of the best glass surface can happen because of vandalism, warm pressure, dealing with, wind or amid establishment, upkeep, and transportation of modules to their establishment destinations [3 and 4]. Kept dust on a PV module decreases the brightening by retaining and scrambling daylight gotten solar cells.

The primary target of this paper is to think about different PV reproduction programming projects and to do execution investigation of grid connected PV plant and to look at real information and assessed information found from various virtual software's. This will give a fundamental knowledge to an analyst to distinguish and use appropriate reenactment programming proficiently and adequately. In this examination 8 photovoltaic simulation software's to be specific SAM, PVsyst, HOMER, PV*SOL, RETScreen, Solarius PV, HelioScope, Solar Pro, SOLARGIS, and PV F-Chart are talked about. Near investigations of these virtual products alongside their restrictions, points of interest, kind of examination, and accessibility have moreover been distinguished.

\section{Software Tools For Photovoltaic System}

In this segment, the fundamental highlights of 10 simulation software's created for photovoltaic framework configuration are talked about alongside a near investigation. The examination results will be then utilized for designing the PV Grid connected Power Plant.The following flowchart presented in fig.1 explains process of design ofgrid connected PV Power plant.

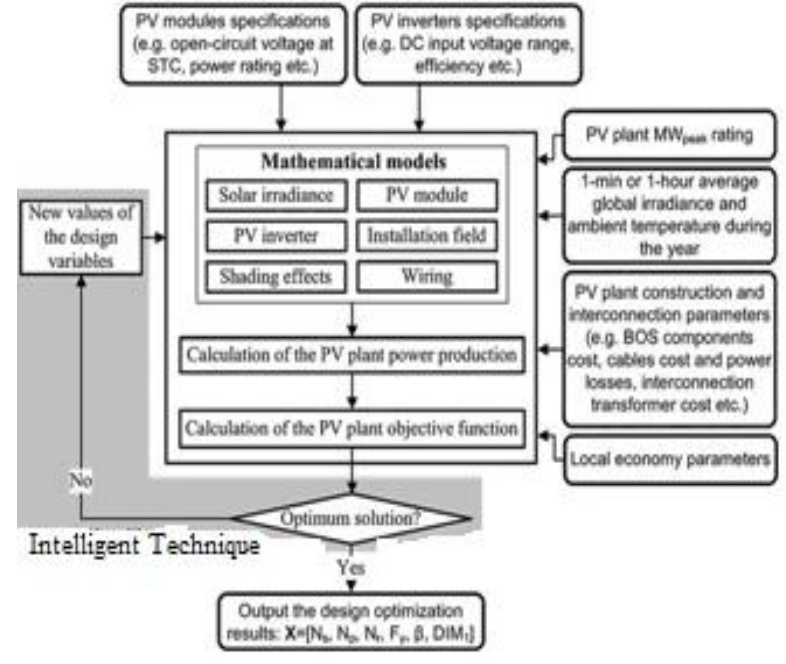

Fig 2:-Flowchart for Design of PV grid connected Power Plant

\subsection{System Advisor Model (SAM)}

The System Advisor Model (SAM) is an execution and cost analysis model intended to encourage choice making for individuals engaged with the sustainable power source and, it is open accessible programming created by the National Renewable Energy Laboratory (NREL) in a joint effort with Sandia National Laboratories, USA [7]. The first version was invented in August 2007; consequently, two new forms have been discharged each year, including new advancements and budgetary models. Since the invention, more than 35,000 individuals have downloaded the product. SAM keeps running on the two Windows and OS X with a visual C++ programming dialect. SAM utilizes climate from NREL's National Solar Radiation Database (NSRDB), SAM utilizes inputs like module type, inverter details, framework plan, and lifetime and so on to recreate framework setup and makes execution expectations and cost of source gauges for network associated control ventures dependent on establishment, working expenses and 
framework structure Parameters that you indicate as contributions to the model. The diagram and table of the SAM model can be sent out to exceed expectations or content documents.

The fundamental restrictions of SAM are as per the following:

1. 3D shade demonstrating for PV frameworks isn't upheld.

2. No accessible climate information for all locations

\subsection{Photovoltaic System (PVsyst)}

PVsyst is software for the investigation, estimating and information examination of finish PV frameworks. It associate with grid connected and standalone AC and DC-framework PV frameworks, and incorporates extensive meteorological and PV frameworks segments databases, and additionally broad solar oriented vitality instruments.PVsystis created by Swiss physicist Andre Mermoud and electrical designer Michel Villoz [8]. This product is considered a standard for PV framework plan and reproduction around the world, the most recent form is V6 and it has 30-days assessment mode for DEMO, boundless variant is around USD 1,021.PVsyst V6 keeps running under any Windows working framework also, Import illumination information from PVGIS and NASA databases. PVsyst has four (4) primary highlights which incorporate Fundamental Design, Project Design, Databases, and Tools. It utilizes inputs like plane introduction (with the plausibility of following planes or shed mounting), framework parts, PV exhibit (number of PV modules in arrangement also, parallel), inverter demonstrate, battery pack and so forth to play out the reproduction. Results will be created which incorporate a few many renewal factors, which might be in month to month, day by day or hourly qualities. A report may be printed for every reenactment run, including all parameters utilized for the recreation, and the fundamental outcomes. A definite financial assessment can be performed utilizing genuine part costs, any extra expenses, and venture conditions. PVsyst has some restriction as pursues:

1. Program screen can't be augmented subsequently can be monotonous to see all parameters if utilizing a little screen.

2. Inability to deal detailed shadow analysis

3. Nosingle linediagram is being created.

\subsection{Hybrid Optimization Model for Electric Renewable (HOMER)}

Homer is micro grid streamlining programming created by NREL (National Renewable Energy Research center), USA [9] and later upgraded and disseminated by Homer Energy that accompanies Simulation, Enhancement, and Sensitivity Analysis instruments. It is the worldwide standard for optimizing grid connected Plant and island utilities to network associated grounds and army installations.. This programming application is utilized to structure and assess in fact and monetarily the choices for off-grid and ongrid control frameworksfor remote, independent and appropriated age applications. HOMERsimulation is done by energy balancing in each time step (interim) of the year and looks at the electric and thermal power in that time venture to the energy that the framework can supply in that time step, and computes the stream of energy to and from every segment of the framework. For frameworks that corporate batteries or fuel-controlled generators, HOMER likewise settles on each time step how to work the generators and whether to charge or release the batteries.. The new HOMER Optimizer utilizes a restrictive subordinate free calculation to scan for the slightest exorbitant framework and after that shows a rundown of setups, arranged by net present expense (some of the time called life-cycle cost), that client can use to think about framework plan choices. HOMER likewise shows recreation results in a wide assortment of tables and charts that assistance client think about arrangements and assess them on their monetary and specialized benefits. Tables and diagrams can be traded for reports and introductions. HOMER Pro keeps running on all Windows Operating Systems that are right now bolstered by Microsoft. The most recent adaptation of Homer Pro is Version 3.11 .5 and was discharged on March 23, 2018; with a buy alternative of around 160 USD every month relies on the sort of bundle. The 21-day free preliminary variant is accessible. The constraints of HOMER are as per the following:

1. Inability to visitor missing qualities or sizes

2. Sophisticated and tedious

3. Detailed info information is required

\subsection{PV*SOL premium}

$\mathrm{PV} *$ SOL premium is German programming created by Valentine Software [10] for dynamic recreation program with 3D perception and enhanced shading analysis of photovoltaic system. PV system originators, architects, advisors, and installers can utilize the product to professionally plan PV frameworks. PV*SOL keeps running under Windows Vista, Windows 7, Windows 8 and Windows 10 with Screen Resolution of no less than 1024 x 768 pixel. This product has 3D Design for3D representation of structures, shading objects, Drag-and-drop shading objects, 
vivified sun-way, Shade recurrence appropriation, shade examination for every individual module. The client can likewise choose Number of secured territories, Number of PV-Module, Number of inverters, PV Generator yield, Orientation, Azimuth, tendency, and Installation Type. The model can perform economic analysis and execution examination with a exhaustive report which can be traded to exceed expectations. The most recent variant is PV*SOL Premium 2018 was discharged on 23rd March 2018. The impediments are as per the following:

1. Sensitivity examination is excluded

2. Error in the introduction of a circuit diagrams

3. Calculations are not advanced

\subsection{Renewable Energy Technologies Screen (RETScreen)}

RETScreen Expert is a far reaching Clean Energy Management Software stage which empowers experts and chiefs to recognize and evaluate the reasonability of potential energy proficiency, sustainable energy, and cogeneration ventures; and to quantify and confirm the genuine and progressing energy execution of structures, industrial facilities and power plants the world over. The product is created by the Government of Canada as a team with eminent global accomplices [11] and is utilized by more than 525,000 individuals in each nation and region of the world.The first form of RETScreen was discharged on April 30, 1998. This model incorporates various databases to help the client, counting a worldwide database of climatic conditions got from 6,700 ground-based stations and NASA satellite information; it can likewise incorporate benchmark database, cost database, venture database, hydrology database and item database. This product can perform possibility and execution examination including vitality investigation, cost investigation, emanation examination, money related investigation, and affectability/chance examination [12]. RETScreen Expert most recent form wasreleased to the general population on September 19, 2016, and is accessible for download totally complimentary in Viewer mode. The full usefulness of RETScreen Expert (counting the capacity to spare, print and fare records) is accessible in Professional mode by buying a sustainable year membership, at present estimated at CAD 869 for each buying in. The more established variant of the product, RETScreen Suite, is made accessible for nothing out of pocket upon demand. A portion of the restrictions are as per the following:

1. Inability to spare, print and fare records when utilizing free view mode rendition.

2. Data sharing issue.

3. No choice for time arrangement information records to Import.

\subsection{Solarius PV}

Solarius PV is the expert Solar PV programming software created by Italian organization ACCA programming [13] for structuring photovoltaic frameworks to accomplish the economic analysis and specialized arrangement. This model uses input like climate information, modules, inverters, batteries and so forth to get specialized and monetary investigation for framework design. Solarius PV can compute the PV framework's general execution (add up to yearly creation with a hourly generation rate plan) and evaluate the benefit and amortization time of the whole photovoltaic framework. These products permits checking the impacts of shading anticipated onto the PV modules by close-by impediments, for example, recieving wires and smokestacks and graphically see shadow obstructions. Solarius PV keeps running under Windows 7, Windows 8, Windows 8.1 or Windows 10 with least 512 MB of memory. Themost recent rendition is Solaris PV v.14.00c and was on discharged thirteenth July 2016, a secret word is expected to introduce one month free preliminary rendition. A portion of the constraints of this product are as per the following:

1. It is less easy to use contrasted with other programming.

2. Advanced plausibility examination isn't upheld.

3. Internet association is required forestablishment.

\subsection{HelioScope}

HelioScope is another program presented by Folsom Lab USA [14] for structuring photovoltaic framework; it has a few highlights of PVSyst and includes the structure usefulness of AutoCAD, enabling fashioners

to complete a finish structure with one bundle. Area's location, exhibit setup, and PV module and inverter detailare the fundamental sources of info required by HelioScope. This product enables the client to assess energy creation that represents misfortune because of climate and atmosphere. Shading, wiring, segment efficiencies, board crisscrosses, and maturing can likewise be dissected so as to give proposals to hardware and cluster design. This instruments showed yearly generation, climate informational collection, execution proportion and other framework parameters for reenactment results. HelioScope has restrictions as pursues:

1. Does not carry on economic analysis 
2. Does not bolster reliable investigation

3. Advance logical computation isn't upheld

\subsection{Solar Pro}

Solar based pro is strong PV plan and vitality reenactment programming created by Japanese organization Laplace Frameworks [15] alongside coordinated 3D-CAD, propelled 3D shading investigation and activity, and precise sun powered power age counts. This product is utilized to make 3D models of private, business flatroof, groundmounted and single and double pivot tracker PV frameworks. It enables clients to imagine shading and design module inclusion effortlessly and precisely. IV Curve figuring's are performed at the module level and consider illumination and temperature information, shading, and other point by point misfortune factors. Altered reports can be created to demonstrate itemized misfortunes, IV-bend diagram, and influence age chart, shading coded cluster hanging arrangement, and shading impacts. The CAD model can be imprinted in any view, and dimensioned formats can additionally be produced and sent out. The primary adaptation of Solar Pro is discharged in1997; the recent variant of Solar Pro is 4.5 .

Table1:-Tabular description of simulation software's of PV Plant

\begin{tabular}{|c|c|c|c|c|c|}
\hline Software & Developed by & $\begin{array}{l}\text { Type of } \\
\text { Analysis }\end{array}$ & Advantages & Disadvantages & Latest Version \\
\hline HOMER & $\begin{array}{l}\text { National } \\
\text { Renewable } \\
\text { Energy } \\
\text { Laboratory } \\
\text { (NREL),USA }\end{array}$ & $\begin{array}{l}\text { Optimizat } \\
\text { ion and } \\
\text { Sensitivit } \\
\text { y analysis; } \\
\text { Technical } \\
\text { analysis; } \\
\text { Financial } \\
\text { analysis }\end{array}$ & $\begin{array}{l}\text { Determines } \\
\text { the } \\
\text { possible } \\
\text { combinations } \\
\text { of a list } \\
\text { of different } \\
\text { technologies } \\
\text { and its } \\
\text { size; } \\
\text { Very detailed } \\
\text { results } \\
\text { for analysis } \\
\text { and } \\
\text { evaluation; } \\
\text { otimization } \\
\text { algorithms } \\
\text { used for } \\
\text { feasibility and } \\
\text { economic } \\
\text { analysis }\end{array}$ & $\begin{array}{l}\text { Inability to } \\
\text { guest } \\
\text { missing values } \\
\text { or } \\
\text { size; } \\
\text { Sophisticated } \\
\text { and } \\
\text { time } \\
\text { consuming; } \\
\text { Detailed input } \\
\text { data is needed }\end{array}$ & $\begin{array}{l}\text { Version } \\
3.11 .5 \\
\text { released } \\
\text { on March } \\
23,2018\end{array}$ \\
\hline PV*SOL & $\begin{array}{l}\text { Valentine } \\
\text { Energy } \\
\text { Software, } \\
\text { Germany }\end{array}$ & $\begin{array}{l}\text { Shading } \\
\text { analysis } \\
\text { and 3D } \\
\text { visualizati } \\
\text { on; } \\
\text { Performan } \\
\text { ce } \\
\text { analysis; } \\
\text { Economic } \\
\text { analysis }\end{array}$ & $\begin{array}{l}\text { Vast } \\
\text { meteorological } \\
\text { database with } \\
\text { over } \\
8000 \text { climatic } \\
\text { location } \\
\text { worldwide; } \\
\text { Strong module } \\
\text { and } \\
\text { inverter } \\
\text { database } \\
\text { with over } \\
13000 \\
\text { modules and } \\
3100 \\
\text { inverters; } \\
\text { Manually add }\end{array}$ & $\begin{array}{l}\text { Sensitivity } \\
\text { analysis is not } \\
\text { supported; } \\
\text { Complexity in } \\
\text { building and } \\
\text { site } \\
\text { modeling; } \\
\text { Error in the } \\
\text { presentation } \\
\text { of } \\
\text { circuit } \\
\text { diagram; } \\
\text { Advanced } \\
\text { scientific } \\
\text { calculation is } \\
\text { not } \\
\text { supported }\end{array}$ & $\begin{array}{l}\text { PV*SOL } \\
\text { Premium } \\
2018 \\
\text { released } \\
23 \text { rd } \\
\text { march, } \\
2018\end{array}$ \\
\hline
\end{tabular}




\begin{tabular}{|c|c|c|c|c|c|}
\hline & & & $\begin{array}{l}\text { custom } \\
\text { modules and } \\
\text { inverters }\end{array}$ & & \\
\hline RETScreen & $\begin{array}{l}\text { Natural } \\
\text { Resources } \\
\text { Canada }\end{array}$ & $\begin{array}{l}\text { Benchmar } \\
\text { k analysis; } \\
\text { Feasibility } \\
\text { analysis; } \\
\text { Performan } \\
\text { ce } \\
\text { analysis; } \\
\text { Portfolio } \\
\text { analysis }\end{array}$ & $\begin{array}{l}\text { Strong } \\
\text { meteorological } \\
\text { and } \\
\text { product } \\
\text { database; } \\
\text { Contains } \\
\text { extensive } \\
\text { integrated } \\
\text { training } \\
\text { material; } \\
\text { High strength } \\
\text { in } \\
\text { financial } \\
\text { analysis }\end{array}$ & $\begin{array}{l}\text { Inability to } \\
\text { save, } \\
\text { print and } \\
\text { export } \\
\text { files when } \\
\text { using } \\
\text { free view } \\
\text { mode } \\
\text { version; } \\
\text { Data sharing } \\
\text { problem; } \\
\text { No option for } \\
\text { time series } \\
\text { data } \\
\text { files Import; } \\
\text { Does not } \\
\text { support } \\
\text { advanced } \\
\text { calculations. }\end{array}$ & $\begin{array}{l}\text { RETScree } \\
\text { n Expert } \\
\text { released } \\
\text { on } \\
\text { September 19, } \\
2016 .\end{array}$ \\
\hline
\end{tabular}

\begin{tabular}{|c|c|c|c|c|c|}
\hline Software & Developed by & $\begin{array}{l}\text { Type of } \\
\text { Analysis }\end{array}$ & Advantages & Disadvantages & $\begin{array}{l}\text { Latest } \\
\text { Version }\end{array}$ \\
\hline SAM & $\begin{array}{l}\text { National Renewable } \\
\text { Energy Laboratory } \\
\text { (NREL), USA. } 2007\end{array}$ & $\begin{array}{l}\text { Performance } \\
\text { analysis; } \\
\text { Economic } \\
\text { analysis }\end{array}$ & $\begin{array}{l}\text { user friendly; } \\
\text { easy to understand; } \\
\text { graphical } \\
\text { representation of } \\
\text { results; } \\
\text { Manually add } \\
\text { custom } \\
\text { modules and } \\
\text { inverters }\end{array}$ & $\begin{array}{l}\text { 3D shade } \\
\text { modeling is not } \\
\text { version } \\
\text { supported; } \\
\text { No available } \\
\text { weather data for } \\
\text { other locations of } \\
\text { the world }\end{array}$ & SAM 2017 \\
\hline $\begin{array}{l}\text { Solarius } \\
\mathrm{PV}\end{array}$ & $\begin{array}{l}\text { ACCA } \\
\text { software, } \\
\text { Italy }\end{array}$ & $\begin{array}{l}\text { Technical } \\
\text { analysis; } \\
\text { Economic } \\
\text { analysis; } \\
\text { Shading } \\
\text { analysis }\end{array}$ & $\begin{array}{l}\text { Extensive } \\
\text { meteorological } \\
\text { database; } \\
\text { Numerical and } \\
\text { graphical results can } \\
\text { be easily exported; } \\
\text { Has photographic } \\
\text { simulation feature }\end{array}$ & $\begin{array}{l}\text { Less user- } \\
\text { friendly as } \\
\text { compared to } \\
\text { other softwares } \\
\text { Advanced } \\
\text { feasibility } \\
\text { analysis is not } \\
\text { supported; } \\
\text { Internet } \\
\text { connection is } \\
\text { required for } \\
\text { installation }\end{array}$ & $\begin{array}{l}\text { Solaris } \\
\text { PV } \\
\text { v.14.00c } \\
\text { released } \\
\text { on 13rd } \\
\text { July, 2016 }\end{array}$ \\
\hline PVsyst & $\begin{array}{l}\text { Institute of } \\
\text { Environmental } \\
\text { Sciences (ISE), } \\
\text { University of } \\
\text { Geneva, Switzerland }\end{array}$ & $\begin{array}{l}\text { Performance } \\
\text { analysis; } \\
\text { Financial } \\
\text { estimation } \\
\text { used for } \\
\text { both grid- } \\
\text { connected } \\
\text {, stand- } \\
\text { alone, }\end{array}$ & $\begin{array}{l}\text { Extensive } \\
\text { meteorological and } \\
\text { PV systems } \\
\text { components } \\
\text { databases; } \\
\text { Has ability to } \\
\text { identify } \\
\text { the weaknesses of } \\
\text { the }\end{array}$ & $\begin{array}{l}\text { Program screen } \\
\text { cannot be } \\
\text { maximized to } \\
\text { enable user to see } \\
\text { all parameters if } \\
\text { using a small } \\
\text { monitor; } \\
\text { Inability to } \\
\text { handle shadow }\end{array}$ & $\begin{array}{l}\text { PVsyst } \\
\text { version } \\
6.70 \\
\text { released } \\
\text { on 29th } \\
\text { March, } \\
2018\end{array}$ \\
\hline
\end{tabular}




\begin{tabular}{|l|l|l|l|l|l|}
\hline & $\begin{array}{l}\text { pumping } \\
\text { and DC- } \\
\text { grid PV } \\
\text { systems, }\end{array}$ & $\begin{array}{l}\text { system design } \\
\text { through Loss } \\
\text { Diagram; } \\
\text { Results include } \\
\text { several dozens of } \\
\text { simulation variables }\end{array}$ & $\begin{array}{l}\text { No single line } \\
\text { diagram }\end{array}$ & \\
& & & \\
\hline
\end{tabular}

\section{Conclusion:-}

Various Simulation software's are reviewed in this paper for photovoltaic system along with comparison table. The fundamental methods of module degradation found in the plant are due to discoloration and glass shattering, staining is because of present ofultra-violet radiation at high temperature while glass shattering happened because of inappropriate taking care of amid transportation, installation and support. Besides these defects, dust gatherings on a large portion of the modules affects the efficiency and performance of plant it very well may be overwhelmed by standard cleaning of the modules.Outcomes from study of different software's are as follows:

1. Out of the 8 reproduction programming projects, Homer, SAM and PVsyst are observed to be the most broadly utilized and best apparatuses as a result of their capacity to do numerous investigations which makes it less demanding and quicker to assess distinctive framework designs.

2. Homer, PVsyst, PV*SOL, SOLARGIS AND SAM are simulation software's are refreshed latest in 2018.

3. All 8 software's have different restrictions for taking care of specific issues, with few having minor confinements. There is requirement for a few enhancements for these simulation software's, such as enabling client to adjust or change a few strategies, more easy to understand, joining of more climate information for other area on the planet, and further developed specialized and financial examinations.

4. Homer, Solarius PV, SOLARGIS, SAM and PV F-Chart are observed to be the best and reasonable programming for execution investigation in this area as a result of closeness of their performance ratio to that of real proportion ratios.

\section{References:-}

1. Turcotte D, Ross M Sheriff F., 2001. Photovoltaic hybrid system sizing and simulation tools: status and needs. In: PV Horizon: work shop on photovoltaic hybrid systems, Montreal; 1-10.

2. Mani, M. and R. Pillai, Impact of dust on solar photovoltaic (PV) performance: Research status, challenges and recommendations. Renewable and Sustainable Energy Reviews, 2010. 14(9): p. 3124-3131.

3. Czanderna A. W. and Pern F. J., "Encapsulation of PV modules using ethylene vinyl acetate co-polymer as a pottant: A critical review," Sol. Energy Mater. Sol. Cells, vol. 43, pp. 101-181, 1996.

4. Chattopadhyay S., Dubey R., Kuthanazhi V., John J. J., Solanki C. S., Kottantharayil A., Arora B. M, Narasimhan K. L., . Kuber V, Vasi J., Kumar A., and Sastry,O. S. "Visual Degradation in Field-Aged Crystalline Silicon PV Modules in India and Correlation with Electrical Degradation," IEEE Journal of photovoltaics, vol. 4, pp. 1470-1476, 2014.

5. Elminir, H.K., et al., Effect of dust on the transparent cover of solar collectors. Energy Conversion and Management, 2006. 47(18-19): p. 3192-3203.

6. SunandaSinha, Chandel S.S., 2014. Review of software tools for hybrid renewable energy systems. Renewable and Sustainable Energy Reviews 32 (2014), 192-205. Energy Reviews 32 (2014), 192-205.

7. Reliability Criteria in Optimal Sizing of Stand-alone Hybrid Wind-PV- Battery bank System.

8. Rahman S, Kwa-sur T. A feasibility study ofphotovoltaic-fuel cell hybrid energy system. IEEETransEnerg Convers 1988; 3(1):50-5.

9. R. Banos a, F. Manzano-Agugliaro b,*, F.G. MontoyaOptimization methods applied to renewable andsustainable energy: A review ElsevierRenewable and Sustainable Energy Reviews 15 (2011) 1753-1766.

10. Buckeridge JS, Ding JJ. Design considerationsfor a sustainable hybrid energy system. IPENZTransactions 2000; 27(1):1-5.

11. Md.Ibrahim et al HybridWind/PV/Diesel Generation in a Stand-Alone Power System Using MarkovBased Genetic Algorithm IEEE TRANSACTIONS ON POWERDELIVERY, VOL. 27, NO. 2, APRIL 2012. Int. Journal of Engineering Researchand Applications www.ijera.com ISSN: 2248-9622,Vol. 5, Issue 8, (Part - 1) August 2015, pp.42-48

12. AzadehKamjoo, AlirezaMaheri and Ghanim A.Putrus. Reliability Criteria in Optimal Sizing ofStand-alone Hybrid Wind-PV-Battery bankSystem2012 2nd International Symposium on Environment Friendly Energies and Applications(EFEA) 
13. Ying-Yi Hong, Ruo-Chen Lian. Optimal Sizingof Y. J. Reddy, K. P. Raju, and Y. V. P. Kumar,-Real time and highfidelity simulation of hybridpower system dynamics, in Proc. IEEE Int. Conf.Recent Adv. Intell. Comput. Syst., Sep. 2011.

14. Lu Zhang1, Georges Barakat, Adnan YassineDesign and optimal sizing of hybrid PV/wind/dieselsystem with battery storage by using DIRECT searchalgorithm. 15th International Power Electronics andMotion Control Conference, EPE-PEMC 2012 ECCEEurope, Novi Sad, Serbia.

15. B. Tudu, S. Majumder, K. K. Mandal and N.Chakraborty Optimal Unit Sizing of Stand-aloneRenewable Hybrid Energy System Using BeesAlgorithm

16. J. Kabouris and G. C. Contaxis, - Autonomoussystem expansion planning considering renewableenergy sources-A computer package,|IEEETrans.Energy Convers., vol. 7, no. 3, pp. 374-381, Sep.1992.

17. J. Kabouris and G. C. Contaxis, -Optimumexpansion planning of an unconventional generationsystem operating in parallel with alarge scalenetwork,\| IEEE Trans. Energy Convers., vol. 6, no. 3,pp.394-400, Sep. 1991.

18. K. Kusakana* H.J. Vermaak and B.P. Numbi.Optimal sizing of a hybrid renewable energy plantusing linear programming. IEEE PES PowerAffica2012 Conference and ExpositionJohannesburg, SouthAfrica, 09-13 July 2012

19. Shiva Kumar B and Sudhakar K., 2015. Performance evaluation of 10 MW grid connected solar photovoltaic power plant in India. Energy Reports 1 (2015), 184-192.

20. Renu Sharma, SonaliGoel., 2017. Performance analysis of a $11.2 \mathrm{kWp}$ roof top grid-connected PV system in Eastern India. Energy Reports 3 (2017), 76-84.

21. Ayompe, L.M., Duffy, A., McCorack, S.J., Conlon, M., 2011. Measured performance of a $1.72 \mathrm{~kW}$ rooftop grid connected photovoltaic system in Ireland. Energy Convers. Manage. 52 (2), 816-825.

22. Ahmad M. K, Indradip M, Werner W, Volker S., 2016. Performance ratio - Crucial parameter for gridconnected PV plants. Renewable and Sustainable Energy Reviews 65 (2016), 1139-1158.

23. Packard C. E., Wohlegemuth J. H., and Kurtz S. R., "Development of a visual inspection data collection tool for evaluation of fielded PV module condition," Nat. Renew. Energy Lab., Golden, CO, USA, Tech. Rep. NREL/TP-5200-56154, Aug. 2012. 